\title{
Creating the Positive Emotional Background Based on Teaching Situations in Process of Building Mathematical Students' Competence
}

\author{
Emilia Dibrivna \\ Candidate of Pedagogical Sciences, National University of Life and \\ Environmental Sciences of Ukraine
}

Svitlana Savchuk

Senior Lecturer of the Department of higher and applied mathematics, National University of Life and Environmental Sciences of Ukraine

\author{
Alina Stepova \\ Student, National University of Life and Environmental Sciences of Ukraine
}

\begin{abstract}
The effective implementation of the structural-functional model, introduced into the educational process of an educational organization, is facilitated by the determination of the necessary and sufficient pedagogical conditions, which are determined taking into account the specifics of the educational process of the organization and the relationship of these conditions, which structurally form a single, integral complex. This article provides the results of a theoretical analysis of the creation of an emotionally positive background, considered as one of the necessary pedagogical conditions that contribute to the effective implementation of the structural and functional model of pedagogical support for the formation of students' mathematical competence. The article discusses the methodological principles and means of creating an emotionally positive background by a teacher in the process of educational activities of students. The results of a theoretical analysis of the influence of positive and negative emotional states of students on the effectiveness of assimilation of information received within the educational activities are presented.

Keywords: emotionally positive background, pedagogical conditions, formation, mathematical competence, students.

Relevance. Increased focus at the student's mastering in process of gaining knowledge, their analysis and logical processing lead to dominance of intellectual part over the emotional. That is the reason of paying much less attention to an emotional part of cognitive process. Such violation of dialectic of proportion in educational process of rational and emotional experiences makes it less productive, creates the danger of one-sided development, adversely affect the student's personal development as a whole and the forming of particular competence, including connected with logical thinking, for instance, mathematical.
\end{abstract}


The purpose of article - to consider the creating of the positive emotional background based on teaching situations as one of the pedagogical condition of building mathematical students' competence.

Scientists consider emotional component as an inherent element of an educational process, which provides the discovery of potential students' power and stimulate his mental productivity. If there are positive emotions in the process of the perception of educational information they work as beneficial stimulus, boost thought actions, making them more clear, logical and productive. They, meanwhile, help to overcome breaking the mental activity therefore students' efficiency increases.

K. Ushinskiy emphasized the importance of emotions and feelings in the learning process. In his framework creating the techniques, aimed at maintaining positive emotions in class which contributes the interest of disciplines, played an important part [4, p. 405-406].

The confirmation of this idea can be found also through the modern scientists. In the result of researches I. Trachtenberg and S. Rushman have found, that emotional element has a big impact on the nature of human's thought process. As the authors say, on the background of positive emotions the fatigue increases slower. I. Trachtenberg and S. Rushman point out the experiments has shown, that under the influence of positive emotions students' efficiency significantly increased [3].

A similar view has S. Arkhangelsky, noting that perception depends on emotional human condition, impressions and vision. If the classes are interesting, various and emotionally rich (in case of positive emotions), they don't suppress, but stimulate the intellectual work, don't call hindering acts [1].

Based on thesis about the ability of positive emotions to more productive enlightening action, T. Shamova identifies three groups of methodical techniques, that provide preparing students for the active learning [5].

The first group is connected with creation of emotional background for the perception of new information. Unusual beginning of the class can include emotional moments at an early stage of learning action, for example, demonstration of new phenomenon; unconventional explanation, beyond the limits of student perceptions; interesting historical fact etc. 
According to the researcher, to the second technique group are included those ones, linked with identification of practical and theoretical meaning of issue being studied during the drafting the topic of class.

The third technique group is connected with the organization of practical student actions, particularly recalling rules while doing practical actions, various measurements and comparing results.

Taking into account scientists' concepts, in process of learning pedagogical conditions of building mathematical competence students-agrarians we have determined, that one of them is creating the positive emotional background based on teaching situations.

Exploring the issue of emotional regulation of learning action future mechanical engineers of agricultural production, V. Manko gives a definition about emotionality of education, which means the saturation of subject-object relationship «teacher-students» by emotional conditions and worries, which contribute students to forming positive emotionally valuable attitude to the educational and professional activity [2].

In the process of forming students' mathematical competence we are mindful, that positive emotions as a factor of enhancing of the cognitive students' action arises, firstly, under the impact of surrounding environment, where the personality is, and secondly, in itself action, aimed at satisfaction of cognitive needs and motives of action on the condition, that course of action completely satisfy the initial personality motives.

The appearance of positive emotions (interest, excitement, happiness, amazement) has been accompanied by increasing efficiency, activation of cognitive students' action in the process of theoretical and practical preparation, that is why it is advisable to create special conditions for its formation.

On a foundation of completed investigations V. Manko suggests the following methodology of preparation for the classes for the special technical subjects, based on particular sequence of the rules for the ensuring of the positive emotional background:

- the teacher should know, for what purpose and according to which of the functions of teaching and educational process (developmental, encouraging etc.) the impact is carried out on the emotional students scope;

- it is necessary to consider the content of the educational material relative to the goal, set at the class; 
- to analyze the content of the additional sources of information, which have to correspond to the moral and aesthetic essence;

- to choose and organically agree on the methods and techniques of emotional affect according to the goal, the content of education material, age and individual specificities of students group, and also didactic tasks of the class;

- to learn enthusiastically, with the rise: information, absorbed with a feeling, digests easier, memorizes and reproduces better;

- to prevent the monotony in educating, copying the structure of the class, replicating the same techniques, methods, the medium of instruction. The emotional scope does not support replicating even the interesting information. If the information is very fascinating, the first replicating can be accepted by emotional sphere, but in case of replicating again it will switch off the attention. For the conceptually-logical sphere is needed more passive, including reproductive, information replicating, moreover replicating without changing the sequence and content of the material. The aim of the teacher is to find the middle ground with the goal of overcoming this antagonism, inherent to both spheres of human's thought;

- to cultivate and support students the feeling of self-confidence, to encourage any success and progress;

- to keep in touch individually with students and with group in general, insofar as the relationship with the teacher are transported to the students attitude to the subject;

- to connect the education process with the other types of educational activity: research work, performances at the conferences, as much as it expands the scientific outlook of students, keeps the interest to the subject, initiates the need of self-improvement and improving special knowledge for the future profession activity [2].

Conclusion. The positive emotions contribute to the increasing of the efficiency and activation the cognitive students' activity. As a result, the creating of the positive emotional background based on the teaching situations can be one of the pedagogical condition of building mathematical students' competence.

\section{References}

1. Arhangelskiy S. I. Lektsii po teorii obucheniya v vyisshey shkole [Lectures on Theory of Learning in Higher Education] / S. I. Arhangelskiy - M.: Vyissh. shk., 1974. - 384p. 
2. Manko V.M. DinamIka rozvitku piznavalnih interesiv studentiv u protsesi vivchennya spetsialnih distsiplin [Dynamics of development of cognitive interests of students in the process of studying special disciplines] / V.M. Manko // Naukovi zapiski: Zb. nauk.st. Natsionalnogo pedagogichnogo universitetu im. M.P.Dragomanova / Ukd. P.V. Dmitrenko, O.L. Makarenko. - K.: NPU, - 2000. - T. XXXVI. - Ch. 3. - pp. 88 -95 .

3. Trahtenberg I.M., Rashman S.M. Gigiena umstvennogo truda studentov [Hygiene of mental work of students] / I.M. Trahtenberg. - K.: Zdorov'ya, 1973. - 172 p.

4. Ushinskiy K.D. Polnoe sobranie sochineniy / K.D. Ushinskiy. - M.: Izd-vo APN RSFSR, 1950. - T. 9. -628 p.

5. Shamova T.I. Problemnyiy podhod v obuchenii [Problematic approach to teaching] / T.I. Shamova.- Novosibirsk: Zap.-Sib. kn. izd-vo, 1969. - 68 p. 